\title{
HAK PATEN DARI PRODUK MITO
}

\author{
M.Rian Safei \\ 155100045 \\ Fakultas Komputer, 448757153 \\ m.riansafei.student@umitra.ac.id
}

\begin{abstract}
Sederet prestasi telah diraih MITO Mobile ( The Most Favourite, Best Seller Mobile, The Most Innovative Phone) dan merupakan rekanan dari beberapa operator telekomunikasi terbesar di Indonesia. Beragam jenis handphone telah dikeluarkan MITO Mobile, selalu menjadi produk terinovasi , stylish, berteknologi tinggi dengan harga yang terjangkau untuk masyarakat Indonesia.

Selain mengandalkan kualitas produk, Mito Mobile serius meningkatkan after-sales service dengan service centre yang tersebar hampir di seluruh kota di Indonesia, sampai sekarang Mito Mobile merupakan salah satu handphone lokal terbesar di Indonesia dengan channel distribusi yang luas.Saat ini, Mito Mobile memiliki Service Centres /Layanan Purna Jual yang tersebar di hampir seluruh Indonesia dan dengan visi yang kuat untuk menjadi yang terbaik di Indonesia, Mito selalu hadir dengan menawarkan produk-produk berkualitas, berteknologi tinggi, inovatif dengan harga yang terjangkau.

Mito merupakan merek yang mempunyai peluang terkecil dalam mempertahankan kosumennya yaitu 0\% dan merupakan merek yang mempunyai peluang terbesar kehilangan konsumen sehingga pada periode yang akan datang Mito mempunyai pangsa pasar terkecil sebesar $0,7 \%$. Periode kesetimbangan terjadi pada periode ke-24
\end{abstract}

Kata Kunci : Inovasi,Teknologi dan Peluang. 
A. INTRODUCTION

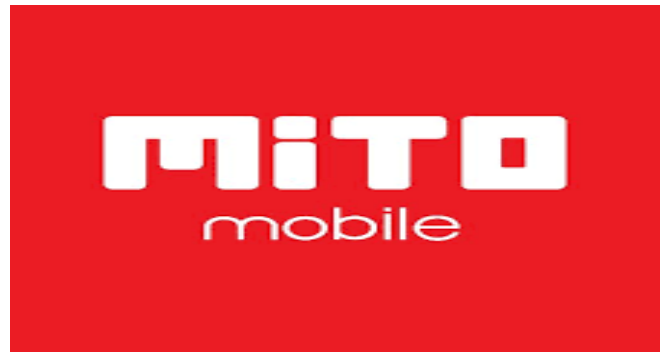

MITO Mobile merupakan salah satu pelopor vendor lokal pertama di Indonesia semenjak tahun 2006. Memasuki penghujung tahun 2012, MITO Mobile berhasil menjadi Top 3 vendor ponsel terbesar di Indonesia dengan pertumbuhan market share yang makin tinggi dan channel distribusi yang merata di seluruh Indonesia.

Selain mengandalkan kualitas produk, Mito Mobile serius meningkatkan after-sales service dengan service centre yang tersebar hampir di seluruh kota di Indonesia. Sampai sekarang Mito Mobile merupakan salah satu handphone lokal terbesar di Indonesia dengan channel distribusi yang luas.

"Beragam jenis handphone telah dikeluarkan MITO Mobile, selalu menjadi produk terinovasi, stylish, berteknologi tinggi dengan harga yang terjangkau untuk masyarakat Indonesia", ujar Hansen Lie ( Direktur Utama Mito Mobile)

Saat ini, Mito Mobile memiliki Service Centres /Layanan Purna Jual yang tersebar dihampir seluruh Indonesia.Dan dengan visi yang kuat untuk menjadi yang terbaik di Indonesia, Mito selalu hadir dengan menawarkan produk- produk berkualitas, berteknologi tinggi, inovatif dengan harga yang terjangkau.
Perusahaan smartphone lokal Mito Mobile tengah mempersiapkan pembangunan pabrik ponsel sendiri. Pembangunan pabrik di daerah Tangerang, Banten ini memiliki kapasitas produksi sekira 1 juta unit perbulan.

"Pabrik kami sudah siap sekarang dengan investasi yang ditanamkan sekira Rp300 miliar," kata Hansen Lie, Direktur Marketing Mito Mobile.

Dan yang tak kalah pentingnya pembangunan pabrik akan membuka lapangan kerja baru bagi putra-putri bangsa terbaik," tuturya. Saat ini, kata Hansen, perusahaan sedang menunggu kebijakan pemerintah mengenai impor bahan sparepart. Diharapkan dengan memiliki pabrik ponsel sendiri, kiprah Mito akan semakin agresif dengan merilis produk berkualitas, kompetitif, unik sesuai dengan segmentasi.

Disisi lain Mito juga banyak mengeluarkan ponsel dengan spesifikasi yang bagus sehingga mampu diandalkan dalam mengolah aplikasi dengan grafis yang cukup tinggi. Seperti halnya Mito Fantasy X A17, ponsel seri terbaru dari Mito ini hadir dengan dilengkapi layar LCD 4,5 inchi yang memiliki resolusi HD 720 pixel. Dengan layar jenis ini Mito Fantasy X A17 ini mampu menampilkan gambar-gambar dengan cukup jernih. Selain itu Mito Fantasy X A17 ini juga di lengkapi dengan dua buah lensa kamera yang masingmasing beresaolusi $2 \mathrm{Mp}$ untuk kamera depan dan $5 \mathrm{Mp}$ untuk kamera belakang, dengan dua lensa kamera ini tentu saja kalian akan lebih mudah 
dalam mengabadikan momentmoment.

(Gambar Mito Fantasi XA17)

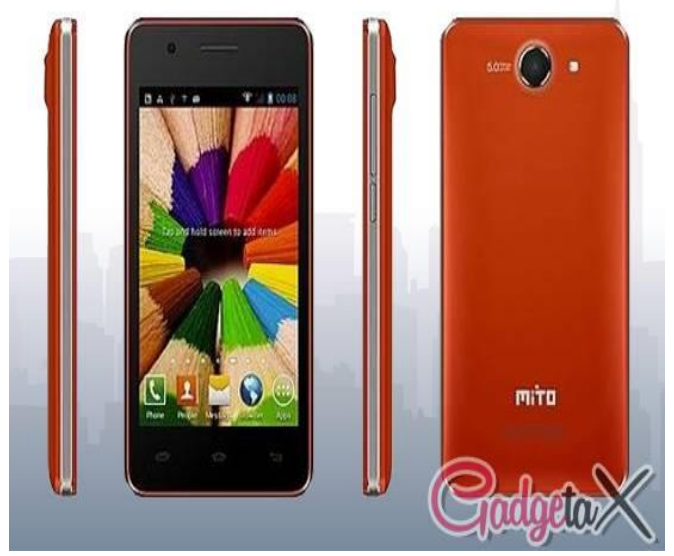

B. CONCLUSION

Kesimpulan nya merupakan salah satu pelopor vendor lokal pertama di Indonesia semenjak tahun 2006 dan Memasuki penghujung tahun 2012, MITO Mobile berhasil menjadi Top 3 vendor ponsel terbesar di Indonesia dengan pertumbuhan market share yang makin tinggi dan channel distribusi yang merata di seluruh Indonesia.

Perusahaan smartphone lokal Mito Mobile tengah mempersiapkan pembangunan pabrik ponsel sendiri. Pembangunan pabrik di daerah Tangerang, Banten ini memiliki kapasitas produksi sekira 1 juta unit perbulan. Dan yang tak kalah pentingnya pembangunan pabrik akan membuka lapangan kerja baru bagi putra-putri bangsa terbaik, perusahaan sedang menunggu kebijakan pemerintah mengenai impor bahan sparepart. Diharapkan dengan memiliki pabrik ponsel sendiri, kiprah Mito akan semakin agresif dengan merilis produk berkualitas, kompetitif, unik sesuai dengan segmentasi.
Beragam jenis handphone telah dikeluarkan MITO Mobile, selalu menjadi produk terinovasi, stylish, berteknologi tinggi dengan harga yang terjangkau untuk masyarakat Indonesia

\section{ACKNOWLEDGEMENT} University Of Indonesia University Of Mitra Indonesia Telkom University University Of Mellbourne Saitama University 
D. REFERENCE(Based ISO 690 )

[1]

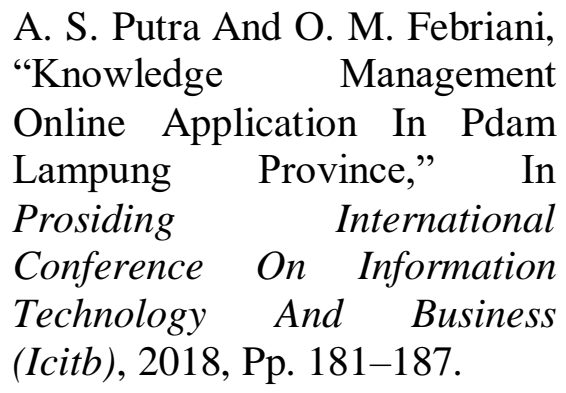

[2] A. S. Putra, O. M. Febriani, And B. Bachry, "Implementasi Genetic Fuzzy System Untuk Mengidentifikasi Hasil Curian Kendaraan Bermotor Di Polda Lampung," J. Sist. Inf. Dan Manaj. Basis Data, Vol. 1, No. 1, Pp. 21-30, 2018.

[3] O. M. Febriani And A. S. Putra, "Sistem Informasi Monitoring Inventori Barang Pada Balai Riset Standardisasi Industri Bandar Lampung," J. Inform., Vol. 13, No. 1, Pp. 90-98, 2014.

[4] Putra, Arie Setya. "2018 Artikel Struktur Data, Audit Dan Jaringan Komputer." (2018).

[5] Putra, A. S. (2018, July 17). Paperplain Fundamental Create Application With Borland Delphi 7.0 University Of Mitra Indonesia. Retrieved From Osf.Io/Pbrn9.

\section{E. REFERENCE (Based APA) $_{\text {(1) }}$}

Putra, A. S., Aryanti, D. R., \& Hartati, I. (2018, November). Metode SAW (Simple Additive Weighting) sebagai Sistem Pendukung Keputusan Guru Berprestasi (Studi Kasus: SMK Global Surya). In Prosiding Seminar Nasional Darmajaya (Vol. 1, No. 1, pp. 85-97).

Sari, D. P., Febriani, O. M., \& Putra, A. S. (2018, November). Perancangan Sistem Informasi SDM Berprestasi pada SD Global Surya. In Prosiding Seminar Nasional Darmajaya (Vol. 1, No. 1, pp. 289-294).

Putra, A. S. (2018). Paperplain: Execution Fundamental Create Application With Borland Delphi 7.0 University Of Mitra Indonesia.

Putra, A. S., Sukri, H., \& Zuhri, K. Sistem Monitoring Realtime Jaringan Irigasi Desa (JIDES) Dengan Konsep Jaringan Sensor Nirkabel. IJEIS (Indonesian Journal of Electronics and Instrumentation Systems), 8(2), 221232.

Darmawan, A., Yuliawati, D., Marcella, O., \& Firmandala, R. (2016). Sistem Absensi dan Pelaporan Berbasis Fingerprint dan SMS Gateway. EXPLORE, 7(1).

Febriani, O. M., Wahyuni, T., \& Yusuf, S. (2017). DESIGN OF WEBSITE-BASED INFORMATION SYSTEM FOR EDOCUMENT ADMINISTRASI IN THE COMMUNITY SERVICE UNIT (A Case Study at Rajabasa District). INTERNATIONAL JOURNAL OF 
COMPUTERS \& TECHNOLOGY, 16(7), 7010-7020.

Febriani, O. M., \& Wahyuni, T. (2017, October). PERANCANGAN SISTEM E-DOCUMENT ADMINISTRASI LOGBOOK PENELITIAN PADA UNIT LAYANAN DI BANDAR LAMPUNG. In Prosiding Seminar Nasional Darmajaya (Vol. 1, No. 1, pp. 187-194).

Febriani, O. M., \& Permadi, A. B. (2017). Implementasi Sistem Aplikasi Data Bimbingan dan Pelanggaran Siswa pada Sekolah Menengah Atas di Lampung Tengah dengan Metode Analisis dan Desain Sistem Terdistribusi (SSAD). EXPERT, 7(1).

Febriani, O. M., \& Ambarwati, L. (2015). PERANCANGAN APLIKASI PENGOLAHAN DATA PENJUALAN UKM KELANTING KHAS TELO DESA SIDOHARJO KECAMATAN JATI AGUNG KABUPATEN LAMPUNG SELATAN. Jurnal Teknologi Informasi dan Bisnis Pengabdian Masyarakat Darmajaya, 1(1), 77-95.

Febriani, O. M. (2015). Rancang Bangun Aplikasi Ecommercemenggunakan Freewebstore pada UKM Kelanting di Desa Sidoharjo Lampung Selatan. Prosiding Sembistek 2014, 1(02), 446-458. 